\title{
Peran Siswa Sekolah Dasar dalam Perubahan Perilaku Pembuangan Sampah Organik dan Pemanfaatan Pembuangan Akhir
}

\author{
Daniah $^{1}$, Ekamaulana Nurzanah $^{2}$, Carwadi $^{3}$ \\ ${ }^{1,2,3}$ Departement Ilmu Kesehatan Masyarakat, Stikes Mitra Husada Indonesia \\ Jl. Manila, No. 37, Sumberece, Tosaren, Kec. Pesantren, Kota Kediri, Jawa Timur 64133 \\ Email: 1r2ddaniah@gmail.com ${ }^{1}$
}

\begin{abstract}
Abstrak
Pendahuluan: Sampah dapat menimbulkan kesehatan dan keselamatan linkungan, bila sampah tidak dikelola dengan baik.

Tujuan: Tujuan dalam penelitian ini adalah siswa SD dapat mengetahui membedakan sampah organik dan non organik, siswa SD juga agar dapat melakukan perubahan dalam memuang sampah ke tempat pemuangan akhir.

Desain: Jenis penelitian ini adalah kuantitatif, menggunakan Quasi Eksperiment. Pengukuran dilakukan sebanyak 2 kali Pre dan post. Dilakukan di SDN Sukaluyu Kec.Teluk Jambe Kab. Karawang. Populasi dalam penelitian ini Siswa Kelas 6 sebanyak 51 orang.

Hasil: Hasil analisis Adanya pengaruh intervensi terhadap pengetahuan meningkat sebesar 8,3 setelah intervensi. Hasil uji statistik menunjukan nilai $\mathrm{P}$ sebesar 0,000 yang berarti intervensi memiliki pengaruh yang signifikan terhadap peningkatan pengetahuan. sikap meningkat sebesar 5,1 setelah intervensi. Hasil uji statistik menunjukan nilai $\mathrm{P}$ sebesar 0,000 yang berarti intervensi memiliki pengaruh yang signifikan terhadap peningkatan skor sikap.

Kesimpulan: Hasil penelitian disimpulkan Ratarata adanya pengaruh kenaikan pengetahuan setelah dilakukan intervensi, dan adanya peruahan perilaku.
\end{abstract}

Kata Kunci: Sampah, TPA, Siswa sekolah dasar

\section{Pendahuluan}

Pencemaran lingkungan akibat sampah semakin mengkhawatirkan apabila tidak ada usaha untuk mengatasinya. Masyarakat yang kurang pengetahuan dan berperilaku buruk dalam pengelolaan sampah dapat menimbulkan gangguan kesehatan dan lingkungan. ${ }^{1,8}$ sampai saat ini selalu menjadi masalah sampah

\begin{abstract}
Introdiction: Waste can cause health and safety of the environment, if the waste is not managed properly.

Objective: The purpose of this research is elementary students can find out the difference between organic and non-organic waste, elementary school students also so they can make changes in dumping rubbish to the final dumpsite.

Design: This type of research is quantitative, using Quasi Experiment. Measurements were made 2 times Pre and post. Performed at SDN Sukaluyu Kec.Teluk Jambe District. Karawang. The population in this study Class 6 students were 51 people.

Result: Results of the analysis The effect of the intervention on knowledge increased by 8.3 after the intervention. Statistical test results show a $P$ value of 0,000 which means that the intervention has a significant effect on increasing knowledge. attitude increased by 5.1 after the intervention. Statistical test results showed a $P$ value of 0,000 , which means that the intervention has a significant effect on increasing attitude scores.

Conclusion: The results of the study concluded the average influence of the increase in knowledge after the intervention, and the exist-
\end{abstract}

Keywords: waste, TPA, elementary school student

dianggap sebagai sesuatu yang kotor dan harus dibuang. Bila dibuang sembarangan akanmenjadi sumber pencemaran lingkungan dan sumber penyakit bagi manusia bahkan bila dibuang pada tempatnya pun bukan berarti masalah terselesaikan, karena timbul permasalahan baru berupa tempat pembuangan akhir. 
Kondisi ini didukung pula oleh perilaku manusia yang memungkinkan terjadinya peningkatan produksi sampah yang mencapai tahap di mana produksi sampah lebih dominan daripada kemampuan untuk memusnahkan sampah yang dihasilkan tersebut. Dengan adanya fakta tersebut maka perlu disadari bahwa partisipasi masyarakat memegang peranan penting dalam upaya pemecahan masalah kesehatan khususnya sampah karena sebagian masalah tersebut muncul akibat perilaku masyarakat itu sendiri. ${ }^{3}$ pemilahan sampah bertujuan memisahkan jenis sampah yang berpotensi menghasilkan emisi gas buang dan abu sisa pembakaran yang berpotensi mencemari lingkungan, seperti logam, plastik, baterai, kertas, bahan cat, ban bekas.

Anak yang mendapatkan pendidikan dan pembinaan sejak dini tentang kesehatan, diharapkan akan dapat memiliki kebiasaan sehat, pengetahuan tentang kesehatan dan dapat bertanggungjawab untuk berperilaku sehat ketika anak tersebut beranjak dewasa. Perilaku kesehatan saat dewasa berhubungan dengan pendidikan kesehatan yang diterima oleh seseorang ketika masa kecil. 'Pengetahuan pada anak usia sekolah merupakan perubahan yang terjadi pada aspek kognitifnya. Daya pikir anak usia sekolah berkembang kearah pikir konkrit, rasional, dan obyektif. Teori Piaget menyatakan pemikiran anak usia sekolah disebut juga pemikiran operasional konkrit (concrete operational thought) yaitu aktivitas mental yang difokuskan pada obyekobyek yang konkrit. ${ }^{4}$ UU No. 18Tahun 2008 tentang Pengelolaan Sampah Rumah Tangga, Rumah Tangga dan Spesifik Mirip sebagai dasar pengelolaan limbah rumah tangga belum dilakukan dengan maksimal, terutama di masyarakat perkotaan.

Perancangan sistem pemilahan, pengeringan dan pembakaran sampah organik rumah tangga yang tepat dapat mengurangi pencemaran lingkungan.

\section{Metode}

Jenis penelitian ini adalah kuantitatif , dengan jumlah populasi 51 anak SD kelas 6 dan sampel dilakukan total populasi, dimana desain penelitian kuantitatifnya menggunakan Quasi Eksperiment. Pengukuran dilakukan sebanyak 2 kali dengan pengukuran pertama pendahuluan sebelum perlakuan dilakukan dan pengukuran kedua dilakukan setelah adanya intervensi. Intervensi dengan memberi informasi tentang Pemilahan sampah dan pembuangan sampah yang tepat. Uji bivariat dilakukan untuk menjelaskan pengaruh intervensi terhadap peningkatan pengetahuan dan sikap responden menggunakan $t$ test dependen, Mc Nemar.

\section{Hasil}

Dari hasil penelitian dan uji statistik yang dilakukan maka hasil terkait pengetahuan anak sekolah dasar tercantum pada tabel dibawah ini

Tabel 1. Pengaruh pengetahuan terhadap sampah organik

\begin{tabular}{lccccc}
\hline $\begin{array}{c}\text { Skor } \\
\text { Pengetahuan }\end{array}$ & N & Mean & SD & SE & $\begin{array}{c}\mathbf{P} \\
\text { Value }\end{array}$ \\
\hline $\begin{array}{l}\text { Sebelum inter- } \\
\text { vensi }\end{array}$ & 51 & 73,3 & 5,7 & 0,8 & \\
$\begin{array}{l}\text { Setelah inter- } \\
\text { vensi }\end{array}$ & 51 & 81,6 & 3,8 & 0,5 & 0,000 \\
\hline
\end{tabular}

Berdasarkan tabel diatas diketahui ratarata skor pengetahuan meningkat sebesar 8,3 setelah intervensi. Hasil uji statistik menunjukan nilai $P$ sebesar 0,000 yang berarti intervensi memiliki pengaruh yang signifikan terhadap peningkatan pengetahuan

Tabel 2. Pengaruh sikap terhadap pemilihan sampah organik

\begin{tabular}{lccccc}
\hline Skor Sikap & $\mathbf{N}$ & Mean & SD & SE & $\begin{array}{c}\text { P Val- } \\
\boldsymbol{u e}\end{array}$ \\
\hline $\begin{array}{l}\text { Sebelum } \\
\text { intervensi }\end{array}$ & 51 & 73,1 & 5,1 & 0,7 & \\
& & & & & \\
$\begin{array}{l}\text { Setelah } \\
\text { intervensi }\end{array}$ & 51 & 78,2 & 7,2 & 1,0 & 0,000 \\
& & & & &
\end{tabular}


Berdasarkan tabel diatas diketahui ratarata skor sikap meningkat sebesar 5,1 setelah intervensi. Hasil uji statistik menunjukan nilai $\mathrm{P}$ sebesar 0,000 yang berarti intervensi memiliki pengaruh yang signifikan terhadap peningkatan skor sikap.

Tabel 3. Pengaruh Perilaku terhadap pemilihan sampah organik

\begin{tabular}{lcccc}
\hline $\begin{array}{c}\text { Skor Per- } \\
\text { ilaku }\end{array}$ & N & $\begin{array}{c}\text { Mean } \\
\text { Rank }\end{array}$ & $\begin{array}{c}\text { Sum of } \\
\text { Rank }\end{array}$ & $\begin{array}{c}\text { P Val- } \\
\boldsymbol{u} \boldsymbol{e}\end{array}$ \\
\hline $\begin{array}{l}\text { Negative } \\
\text { Ranks }\end{array}$ & 5 & 8,9 & 44,5 & 0,000 \\
Positif & 29 & 18,9 & 550 & \\
Ranks & & & & \\
Ties & 17 & & & \\
Total & 51 & & &
\end{tabular}

Dari tabel 3 di atas diketahui nilai negatif ranknya adalah 5 yang menunjukan setelah diberikan intervensi skor perilaku responden ada yang menurun sebanyak 5 orang. Selain itu

diketahui nilai positif rank sebesar 29 yang menunjukan bahwa 29 responden mengalami peningkatan skor perilaku setelah diberikan intervensi dengan Mean Rank atau rata-rata peningkatan tersebut adalah 18,9. Hasil uji statistik menunjukan p-value 0,000 yang berarti ada pengaruh intervensi terhadap peningkatan perilaku responden.

\section{Pembahasan}

Hasil uji statistik menunjukan nilai $\mathrm{P}$ value 0,000 yang artinya memiliki pengaruh yang signifikan setelah dilakukan intervensi terhadap peningkatan pengetahuan siswa, dan sikap mempunyai nilai P-value 0,000 yang artinya setelah dilakukan intervensi memiliki pengaruh yang signifikan terhadap peningkatan sikap siswa.

diketahui nilai negatif ranknya adalah 5 yang menunjukan setelah diberikan intervensi skor perilaku responden ada yang menurun sebanyak 5 orang. Selain itu diketahui nilai positif rank sebesar 29 yang menunjukan bah- wa 29 responden mengalami peningkatan skor perilaku setelah diberikan intervensi dengan Mean Rank atau rata-rata peningkatan tersebut adalah 18,9. Hasil uji statistik menunjukan pvalue 0,000 yang berarti ada pengaruh intervensi terhadap peningkatan perilaku responden $65 \%$ masih banyak orang yang tidak memilih sampah organik, dan masih tercampur menjadi 1 tempat sampah. Dan memuang sampah ke TPA belum terbiasa, sehingga TPA belum dimanfaatkan secara maksimal.

Berdasarkan hasil penelitian (Risan 2012) Hasilnya didapatkan rata-rata sampah rumah tangga yang dihasilkan sebanyak 1,46 liter/orang/hari atau $0,38 \mathrm{~kg} /$ orang/hari, yang terdiri dari $47 \%$ sampah organik, $15 \%$ kertas, $22 \%$ plastik, serta $16 \%$ logam. ${ }^{5}$ Penelitian lain yang dilakukan oleh Apriani (2019) menyatakan bahwa perawat memegang peran penting untuk membantu orang tua menghadapi permasalahan yang berkaitan dengan anak. Fokus intervensi keperawatan yang dilakukan adalah memberikan dukungan psikologis pada anak. ${ }^{6}$ Penelitian yang lain menyatakan bahwa stress yang terjadi pada anak dapat diatasi dengan atraumatic care hal ini dapat dilakukan juga untuk meningkatkan potensi anak dalam hal rasa peduli. ${ }^{7}$ kepedulian anak sangat diperlukan terkait dengan perilaku hidup bersih dan sehat. perilaku hidup bersih dan sehat harus menjadi cerminan untuk semua orang dimulai dari masa kanak-kanak. penelitian yang dilakukan oleh Mustikawati 2011 menyatakan bahwa Risiko yang paling dekat sampah di Tempat Pembuangan Akhir (TPA) adalah penyakit yang terkait dengan lingkungan, sanitasi pribadi, makanan, dan lain-lain. Oleh karena itu perilaku hidup bersih dan sehat harus ditanamkan secara dini.

Menurut asumsi peneliti bahwa memang sebelum dan sesuah dilakukan intervensi atau pelatihan siswa dasar dalam pembuangan dan pemilahan sampah rumah tangga adanya peredaan yang singnifikan, dari segi pengetahuan siswa SD masih banyak yang tidak mengatahui dalam pemilihan sampah dan seebrapa pentingnya manfaat jika dilakukan pemilihan sampah, sehingga setelah dilakukan intervensi pemahaman atau pengetahuan dalam 
memilah sampah rumah tangga jadi mengatahui dan lebih baik. Sedangkan sikap yang selama ini mereka tidak peduli dengan sampah, tidak mau tau sampah rumah angga itu seaiknya di pilah pilah atau tidak, setelah dilakukan intervensi atau pelatihan, sikap siswa SD sangat responsive terhadap pemilahan sampah, terukti dalam oservasi 1 minggu dengan pengawasan kader, siswa SD sudah mengetahui jenis-jenis sampah organik dan sampah non organik. Dan bias memuang sampah ke tempat pemuangan akhir.

\section{Kesimpulan}

Rendahnya kesadaran siwa sekolah dasar dalam melakukan hidup bersih dan sehat, terutama pengetahuan dan sikap dalam memuang sampah, dan memilah sampah rumah tangga, sehingga pengolahan sampah bias dilakukan untuk kegiatan berikutnya. Sehingga meliatkan siswa Sekolah dasar sanggat efektif dalam meruah perilaku sesorang untuk melakukan peruahan, sehingga memeerikan pendidikan kesehatan perlu sedinimungkin agar apa yang di sampaikan akan tereman sampai kapan pun.

\section{Daftar Pustaka}

1. Tobing, Imran SL. "Dampak Sampah Terhadap Kesehatan Lingkungan Dan Manusia." Makalah pada Lokakarya Aspek Lingkungan dan Legalitas Pembuangan Sampah serta Sosialisasi Pemanfaatan Sampah Organik sebagai Bahan Baku Pembuatan Kompos. Kerja sama Universitas Nasional dan Dikmenti DKI. Jakarta (ID) Juni (2005).

2. Pratama, Ryan Aditya. "Perilaku Masyarakat dalam Membuang Sampah di Tempat Penampungan Sementara (TPS) di Kecamatan Pontianak Barat Kota Pontianak." Jurnal Teknologi Lingkungan Lahan Basah 1.1 (2016).

3. Fitriana, Ayu. Perilaku Ibu Rumah Tangga Terhadap Pengelolaan Sampah Di Desa Bluru Kidul Rw 11 Kecamatan Sidoarjo Tahun 2011. Diss. Universitas Airlangga, 2011.

4. Notoatmodjo, S. Promosi Kesehatan dan Ilmu Perilaku. Jakarta: Pt Rineka Cipta; 2007.

5. Riswan, R., Henna Rya Sunoko, and Agus Hadiyarto. "Pengelolaan sampah rumah tangga di Kecamatan Daha Selatan." Jurnal Ilmu
Lingkungan 9.1 (2011): 31-38.

6. Apriani, Vera. "Terapi Bermain Terhadap Perilaku Kooperatif Pada Anak Usia Pra Sekolah." Jurnal Ilmiah Ilmu Keperawatan Indonesia 7.03 (2017): 188-195.

7. Purnama, Agus. "Penerapan Atraumatic Care dengan Medical Play terhadap Respon Kecemasan Anak Usia Prasekolah yang mengalami Hospitalisasi di Ruang Rawat Inap Anak." Jurnal Ilmiah Ilmu Keperawatan Indonesia 8.04 (2018): 516-521.

8. Abrauw, Albert, Hadi Sabari Yunus, and Sri Rum Giyarsih. "Perilaku Masyarakat Dalam Pengelolaan Sampah Anorganik di Kecamatan Abepura Kota Jayapura." Majalah Geografi Indonesia 25.1 (2011): 1-14.

9. Adiwiryono, Retno Mardhiati, M. Kes, and Muhammadiyah Prof DR Hamka. "Pesan Kesehatan: Perilaku Hidup Bersih dan Sehat (PHBS) Anak Usia Dini dalam Kurikulum Pendidikan Anak Usia Dini." Jurnal Ilmu Kesehatan Universitas Muhammadiyah Prov. Hamka (2010).

10. Nurdiyanti, Dewi, Arie Susetio Utami, and Johan Norma Bastian. "Pemanfaatan Limbah Organik Pasar Sebagai Bahan Pupuk Kompos Untuk Penghijauan di Lingkungan Masyarakat Kota Cirebon." URECOL PROCEEDING (2017).

11. Mulyadi, Achmad, Sofyan Husein, and Zulfan Saam. "Perilaku masyarakat dan peranserta pemerintah daerah dalam pengelolaan sampah di kota tembilahan." Jurnal Ilmu Lingkungan 3.02 (2010).

12. Naryono, Eko, and Soemarno Soemarno. "Perancangan Sistem Pemilahan, Pengeringan dan Pembakaran Sampah Organik Rumah Tangga." The Indonesian Green Technology Journal 2.1 (2013): 27-36.

13. Fitriana, Ayu. Perilaku Ibu Rumah Tangga Terhadap Pengelolaan Sampah Di Desa Bluru Kidul Rw 11 Kecamatan Sidoarjo Tahun 2011. Diss. Universitas Airlangga, 2011.

14. Lolowang, Melita Amelia, Franckie RR Maramis, and Budi T. Ratag. "Gambaran Perilaku Hidup Bersih Dan Sehat Di Sekolah Dasar Inpres Talikuran Kecamatan Kawangkoan Utara." Media Kesehatan 9.3 (2017).

15. Mustikawati, Intan Silviana. "Perilaku personal hygiene pada pemulung di TPA kedaung wetan tangerang." Forum Ilmiah. Vol. 10. No. 1. 2013. 